\title{
Toxicity of diatomaceous earth on seed weevil, Sitophilus oryzae L. and its effect on agro-morphological characters of maize seeds
}

\author{
S. Aisvarya* \\ Department of Agricultural Entomology, Tamil Nadu Agricultural University, Coimbatore \\ -641003 (Tamil Nadu), India \\ M. Kalyanasundaram \\ Department of Agricultural Entomology, Tamil Nadu Agricultural University, Coimbatore \\ -641003 (Tamil Nadu), India \\ M. Kannan \\ Department of Nano Science and Technology, Tamil Nadu Agricultural University, Coimbatore \\ -641003 (Tamil Nadu), India

\section{A. Lakshmanan} \\ Department of Nano Science and Technology, Tamil Nadu Agricultural University, Coimbatore \\ -641003 (Tamil Nadu), India \\ T. Srinivasan \\ Department of Agricultural Entomology, Tamil Nadu Agricultural University, Coimbatore \\ -641003 (Tamil Nadu), India \\ *Corresponding author Email id: aisvaryasrinivasan@gmail.com
}

\section{How to Cite}

Aisvarya, S. et al. (2021). Toxicity of diatomaceous earth on seed weevil, Sitophilus oryzae L. and its effect on agro-morphological characters of maize seeds. Journal of Applied and Natural Science, 13(4), 1180 - 1186. https:// doi.org/10.31018/jans.v13i4.3003

\begin{abstract}
Sitophilus oryzae L. (Curculionidae; Coleoptera) is considered to be a serious internal feeder of stored cereals. The use of insecticides results in the development of resistance among the pests and residues in the produce. Diatomaceous Earth (DE) is from a natural source, environment-friendly, safe to humans and natural enemies. In addition, it is highly effective against a wide range of stored pest species and has no toxic residues on the treated seeds. The promising alternative to synthetic insecticides is the application of DE in storage pest management under physical control. With this background, the present study was aimed to find the efficacy of DE against rice weevil, S. oryzae L. and their effect on the agro-morphological characters of maize (Zea mays L.) seeds. Contact toxicity bioassays were carried out with different concentrations of DE against S. oryzae. The results of the bioassay studies revealed $L_{50}$ at the concentration of $1.27 \mathrm{mg} / 100 \mathrm{gm}$ of maize seeds. Further, 100 per cent mortality was achieved at the dose of $15 \mathrm{mg} / 100 \mathrm{gm}$ of maize seeds within six days of exposure. The effect of DE on the germination provided a significant increase in germinability of maize seeds $\left(L_{50}=94 \%, L_{95}=98 \%\right.$ and control $\left.=96 \%\right)$. $D E$ at the concentration of $\mathrm{LD}_{95}$ had a beneficial effect on the seedling parameters, especially germination\% (98\%) and seedling length $(53.02 \mathrm{~cm})$ of maize. The present study concluded that DE could be effectively utilised as an alternative management tool to chemical insecticides in the management of rice weevil under storage conditions.
\end{abstract}

Keywords: Agro-morphological characters, Diatomaceous earth, Maize, Seeds, Sitophilus oryzae, Toxicity

\section{INTRODUCTION}

Diatomaceous earth (DE) is inert dust with amorphous silica as a major component and is made up of fossilised diatoms. The dust colour varies from white to red. Another major component present in the dust is calcium in addition to minor elements like sodium, phosphorous, zinc etc. (Subramanyam and Roesli, 2000). It is an odourless, non-inflammable inert material with $\mathrm{pH}$ vary- ing from slightly acidic to alkaline (4.4-9) (Korunic, 1997). The average size of DE particles ranges from 2.5 to 30 microns. It is said that DE possesses entomotoxic activity because of amorphous silica in uniform size (Korunik, 1997). The major advantage of the usage of inert dust for stored pest management is that they are safe for humans and natural enemies. Hence, DE can be used as a natural insecticide for the longterm protection of stored produces (Korunic et al., 
2017; Ziaee et al., 2019). The possible mechanism behind the insecticidal activity is that they cause abrasion of the integument, especially the waxy layer by strong adherence onto the body of the insect. Insect mortality is brought about by desiccation (Ebeling, 1971). The cuticular water loss rate (CWLR) was found to be higher in weevils treated with DE than those untreated weevils (Prasantha et al., 2015).

$D E$ is used against various storage pests. Athanassiou et al. (2004) compared the effect of DE on the adults of Sitophilus oryzae and Tribolium confusum where adult mortality pattern remained same for the three different concentrations i.e., $0.75,1$, and $1.5 \mathrm{~g}$ of $\mathrm{DE} / \mathrm{kg}$ of grain. Islam et al. (2010) investigated the effects of Protect-It ${ }^{\circledR}$ and SilicoSec ${ }^{\circledR}$ formulations of DE against Callosobruchus maculatus and $\quad$ S. oryzae. Protect-It ${ }^{\circledR}$ was more effective against $C$. maculatus, whereas Sili$\operatorname{coSec}^{\circledR}$ was more effective against $S$. oryzae. Badii et al. (2014) reported that efficacy of DE altered with a change in RH (Relative Humidity). It was found that DE was more effective against $C$. maculatus at $50 \% \mathrm{RH}$ than at $80 \% \mathrm{RH}$. Modified formulations of DE were found to be more effective than original DE. Modified DE formulations like Al-DE and Ca-DE had a more toxic effect on the adults of Sitophilus granarius in wheat kernels (El-Aziz and El-Ghany, 2018).

Commercial formulations available in the market are Dryacide, Dicalite, Diacide, DiaFil, Insecolo, Insectigone, Insecto, Kenite, Melocide, Organic Plus, PermaGuard, Protect-It, Silicosec, Shellshock, etc. (Subramanyam and Roesli, 2000). The insect species that are more subtle to DE belongs to the genus Cryptolestes whereas the most tolerant insects belong to the genus Prostephanus. In addition, Oryzaephilus is said to be less sensitive, Sitophilus as less tolerant and Tribolium and Rhyzopertha as the most resistant ones to DE (Maceljski and Korunic, 1972; Desmarchelier and Dines 1987; Fields and Muir, 1996; Korunic et al., 1997; Korunic and Fields, 1998, 2006).

Cereals are grown to a larger extent to meet out the food demand of humans. Among them, maize (Zea mays) is considered to be a vital crop as it serves as human food and livestock feed. It is grown worldwide and plays a prominent role in the coarse grain trade. According to the Ministry of Agriculture \& Farmers welfare, Government of India, 2018-19 maize production and productivity are $9.18 \mathrm{~m}$ ha, $27.23 \mathrm{MT}$ and $2965 \mathrm{~kg}$ $\mathrm{ha}^{-1}$, respectively. Maize plays a prominent role in coarse grain trade worldwide. The major constraint with maize cultivation is post-harvest loss which accounts for significant yield loss in terms of both production and productivity. Both biotic and abiotic factors bring about post-harvest losses. Storage insect pests play a major role in imposing damage to the maize seeds. More than 37 species of insects inflict damage in storage (Tadese,
1997). Among them, S. oryzae L. causes more economic damage both qualitatively and quantitatively. The use of chemicals to control the pest, led to harmful effects in the environment and resistance development in insects. In this case, DE can be considered as an alternative to chemical insecticides, mainly in the storage environment. If preservation of germination is considered a primary factor in storage, then DE can be chosen to enhance or preserve the germinability of the stored seeds (Omobowale and Akomolafe, 2021). DE can be a preferred seed protectant as a preventive measure rather than a curative one. The current study was aimed to study the toxic effect of diatomaceous earth against rice weevil, $S$. oryzae and its effect on agro-morphological characters of maize seeds.

\section{MATERIALS AND METHODS}

\section{Rearing of Sitophilus oryzae}

The weevils of $S$. oryzae were collected from the infested cereal produces from storage godowns at the Department of Millets, Tamil Nadu Agricultural University (TNAU), Coimbatore, for mass culturing. The weevils were reared on maize grains at room temperature of 27 $\pm 3^{\circ} \mathrm{C}$. Subculturing was done at 15 to 20 days intervals to maintain a continuous supply of insects. Uniform aged adults of one week old were used for bioassay studies. The study material of diatomaceous earth was purchased from SGP industries, Bikaner, India. DE is mainly composed of amorphous silica, alumina and iron oxide.

\section{Toxicity assessment of DE against $S$. oryzae}

Bioassay was performed in a small plastic container and $100 \mathrm{~g}$ of maize seeds were taken in each container. Maize seeds were treated with DE at different concentrations $(0.25 \mathrm{mg}, 0.5 \mathrm{mg}, 0.75 \mathrm{mg}, 1 \mathrm{mg}, 1.5 \mathrm{mg}, 2$ $\mathrm{mg}, 100 \mathrm{mg}, 3 \mathrm{mg}, 4 \mathrm{mg}, 5 \mathrm{mg}, 7.5 \mathrm{mg}, 10 \mathrm{mg}, 12.5$ $\mathrm{mg}$ and $15 \mathrm{mg}$ ) and a control (without any DE treatment) was maintained. Then the containers were shaken manually for approximately $1 \mathrm{~min}$ to achieve equal distribution (Subramanyam and Roesli, 2000). Fifteen pairs of adults were introduced into each container. Four replications were maintained for each treatment in a completely randomized design. Experiments were carried out at $27 \pm 3^{\circ} \mathrm{C}, 70 \% \mathrm{RH}$. Insect mortality (lack of locomotion and or response to repeated probing) was recorded at $24 \mathrm{~h}$ intervals for seven days. The corrected mortality was worked out by the formula given by Abbott. The observations on the percent mortality were subjected to probit analysis and $L D_{50}$ value was worked out.

$$
\text { Corrected }(\%) \text { mortality }=(X-Y) /(100-X) \times 100
$$

$X=$ Percentage mortality in DE treated treatments. 
$\mathrm{Y}=$ Percentage mortality in the untreated check.

\section{Seed germination assessment}

Seed germination studies were carried out by following the methodology given by ISTA (International Seed Testing Association) and Govindaraju et al. (2020). Maize seeds were sterilised with $10 \%$ sodium hypochlorite solution. The seeds were washed and treated with two different concentrations of DE solutions $\left(\right.$ LC $_{50}$ and $\left.\mathrm{LC}_{95}\right)$. A control was maintained by soaking the seeds in water. Twenty-five seeds from each treatment were taken and kept on the germination sheet in equidistant manner. Then, they were rolled and tightened using rubber band. Each treatment was replicated seven times. At the end of 7 days, the seedling parameters like shoot length $(\mathrm{cm})$, root length $(\mathrm{cm})$, dry matter production (g), germination percentage (\%) and vigour index were recorded.

Germination percentage $(\%)=$ Number of strongly Germinated seeds /Total number of seeds $\times 100$

Vigour index $=$ Germination $(\%) \times$ Seedling length .......... Eq. 2

\section{Statistical analysis}

The data were analyzed by completely randomized design (CRD) using SPSS statistical software. Probit regression analysis was carried out by Finney's method (1971). Analysis of variance (ANOVA) was done to determine whether significant difference exists between treatments.

\section{RESULTS AND DISCUSSION}

\section{Toxicity assessment against $S$. oryzae}

The results of the bioassay studies revealed the entomotoxic ability of diatomaceous earth against $S$. oryzae. Probit regression analysis displayed $\mathrm{LD}_{50}$ as 1.27 $\mathrm{mg} / 100 \mathrm{~g}$ and $\mathrm{LD}_{95}$ as $86.11 \mathrm{mg} / 100 \mathrm{~g}$ (Table 1.). Calculated chi-square value was less than the tabular value which indicated that the data perfectly fit into the probit model. $1.27 \mathrm{mg}$ of DE was able to kill $50 \%$ of the insect population in $100 \mathrm{~g}$ of seeds within a period of 7 days. These results are in accordance with the findings of Athanassiou et al. $(2004,2005)$. They have reported that DE at the dose of 1 and $1.5 \mathrm{~g} / \mathrm{kg}$ resulted in higher mortality in the adults of $S$. oryzae and $T$. confusum. Fig.1. shows the light microscopic images of DE treated and untreated rice weevil. DE adheres onto the surface

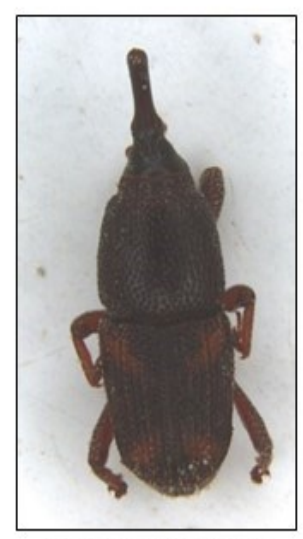

DE untreated rice weevil with null coating

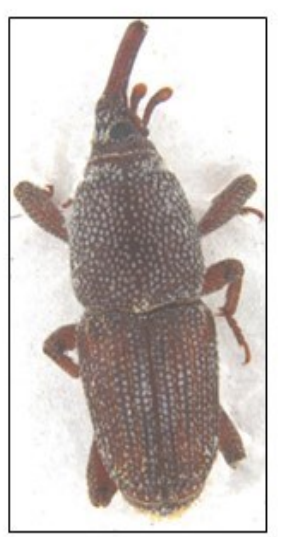

$D E$ treated rice weevil with white patches of DE in the head, thorax and abdominal region
Fig. 1. Difference in DE treated and untreated insects

of rice weevil when it comes in contact with $D E$ treated seeds. By adhering to the integument, DE gets coated on the whole body especially on the head, thorax, abdomen and its appendages. Similarly, the effect of commercial formulation of amorphous DE (Fossil Shield ${ }^{\circledR}$ ) on confused flour beetle, granary weevil, mealworm and Indian meal moth was higher at the dose of 2 and $4 \mathrm{~g} / \mathrm{m}^{2}$ and caused more lethal effects to adults than late larval stages (2-3 weeks old). In general, DE on contact with insects' cuticle causes disruption and dehydration (Mewis and Ulrichs, 2000). Erturk et al. (2020) founded that wettable powder formulation of DE - Detech ${ }^{\circledR}$ was highly working against $S$. oryzae at the concentration of $2 \mathrm{~g} / \mathrm{m}^{2}$. The present results showed $L D_{50}$ value was ten times lower than the previous studies indicating that DE was more toxic at low dose i.e., high insecticidal efficacy.

\section{Toxicity pattern of DE against S. oryzae}

The cumulative pattern of mortality of DE at different concentrations against $S$. oryzae in maize seeds is shown in table 2. Among the various doses used, higher mortality of $80 \%$ was obtained at $7.5 \mathrm{mg} / 100 \mathrm{~g}$ on the $7^{\text {th }}$ day of exposure. On $1^{\text {st }}$ day after release (DAR), more insect death $(6.67 \%)$ was seen at the concentration of $3 \mathrm{mg} / 100 \mathrm{~g}$ with the mortality of $20 \%, 40 \%$ and $60 \%$ in the subsequent days. At the highest dose of 15 $\mathrm{mg} / 100 \mathrm{~g}$, cent percent mortality was achieved within six days of exposure. However, higher mortality at lower dose of $0.25 \mathrm{mg} / 100 \mathrm{~g}$ was only $26.67 \%$. The results revealed that insecticidal activity increased with con-

Table 1. Probit regression analysis of mortality data of DE against $S$. oryzae

\begin{tabular}{|c|c|c|c|c|c|c|}
\hline S. No. & Particulars & $\begin{array}{l}\mathrm{LD}_{50} \mathrm{mg} / 100 \mathrm{~g} \text { of seeds } \\
\text { (95\% fiducial limits) }\end{array}$ & $\begin{array}{l}\text { LD }_{95} \mathrm{mg} / 100 \mathrm{~g} \text { of seeds } \\
\text { (95\% fiducial limits) }\end{array}$ & Slope & $x^{2 *}$ & $\begin{array}{l}\text { Degrees of } \\
\text { freedom }\end{array}$ \\
\hline 1. & $\mathrm{DE}$ & $\begin{array}{l}1.27 \\
(0.74-2.16)\end{array}$ & $\begin{array}{l}86.11 \\
(10.84-683.96)\end{array}$ & 1.011 & 0.147 & 6 \\
\hline
\end{tabular}

* - Calculated $x 2$ value was less than the tabular value $(p=0.05)$, indicating that the data fit the probit model 


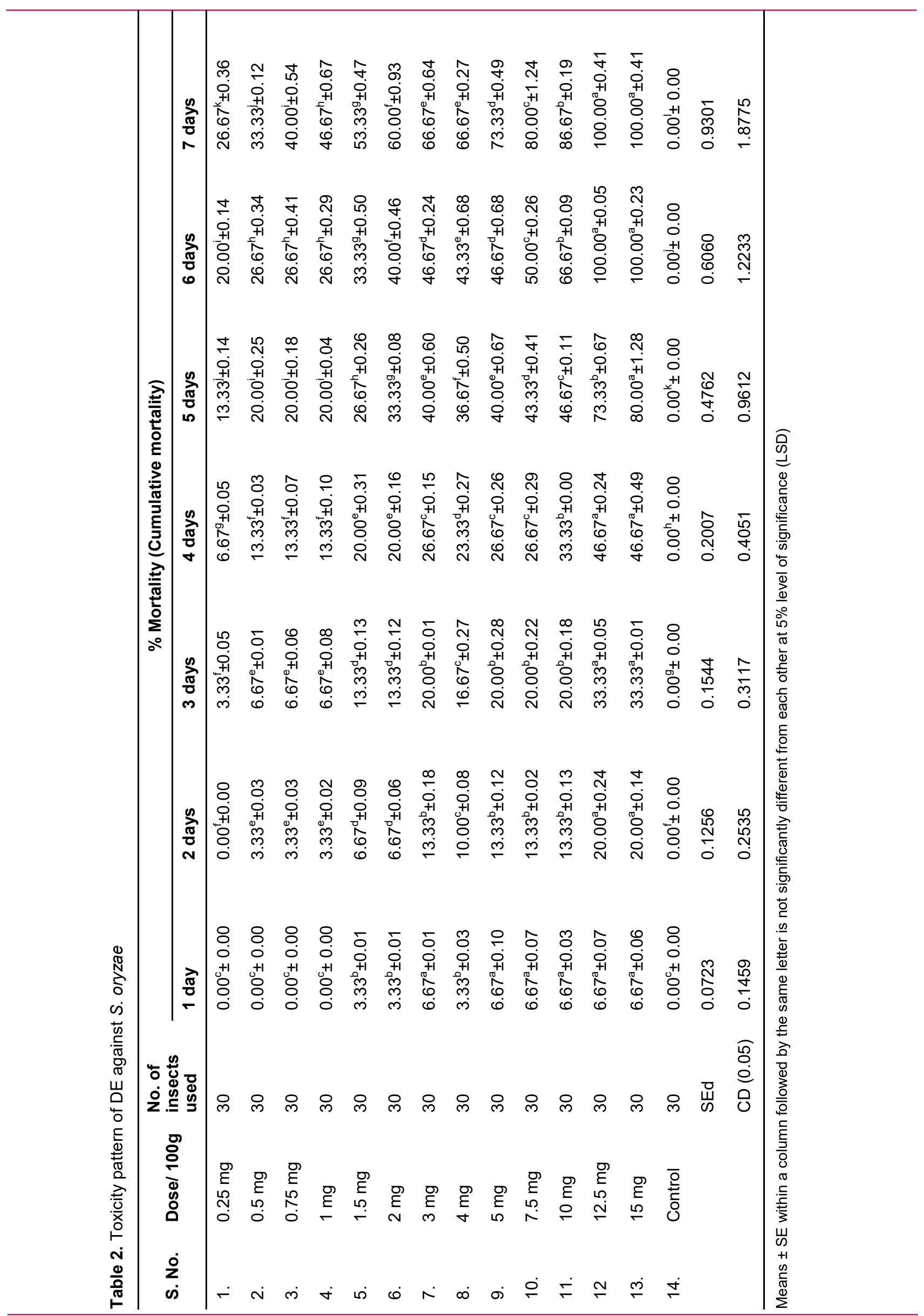




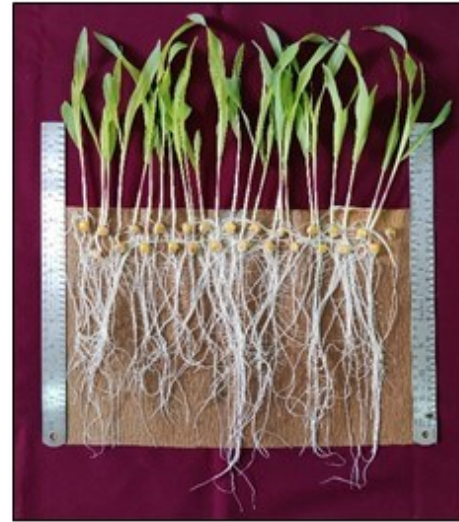

DE - LD $_{50}$ treated seeds showing better shoot and root growth

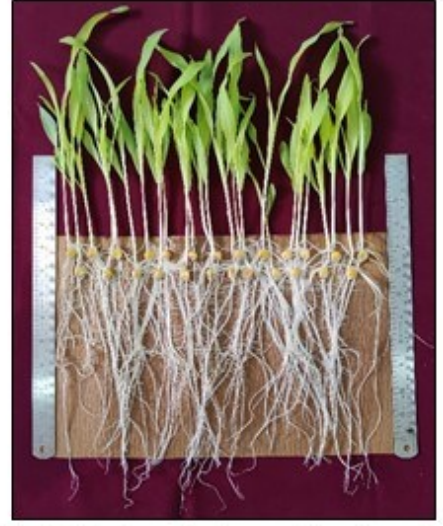

DE - $L D_{95}$ treated seeds showing robust root growth and uniform shoot growth

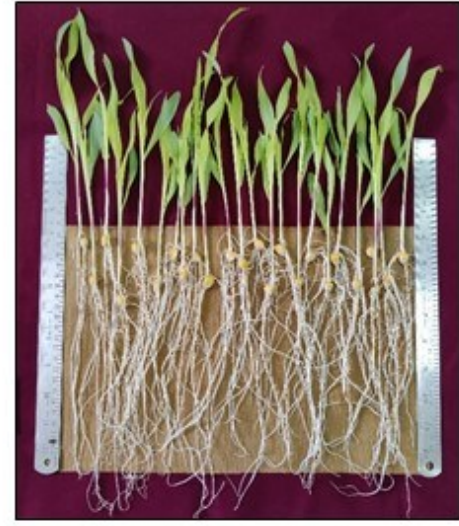

DE untreated seeds showing slender seedlings

Fig. 2. Difference in germination of seeds in different treatments (DE- $L D_{50}, D E-L D_{95}$, Control)

centration and time of exposure of dusts with the insects. By enhancing the formulations of DE (i.e., DE + bitterbarkomycin, DE + Abamectin) higher toxicity can be achieved at very lower doses $(\leq 100 p p m)$. At the same time, DE can be effectively included in an integrated storage pest management programme (Shah and Khan, 2014). DE can be effectually combined with insecticide Spinosad and Trichoderma harzianum to protect wheat grains from rice weevil (Gad et al., 2020). Diatomaceous earth has also been found to be compatible with the fungus Metarhizium anisopliae used against S. oryzae (Athanassiou et al., 2008).

\section{Effect of DE on agro-morphological characters of} maize seeds

The germination studies of maize seeds by roll towel method confirmed the significant differences among the treatments used ( $L D_{50}, L D_{95}$ and control). The observed seedling parameters such as germination\%, root length, shoot length, seedling length, vigour index and dry matter production are listed in table 3. Germination per cent was higher (98\%) in $\mathrm{LD}_{95}$ concentration, whereas it was only $94 \%$ in $\mathrm{LD}_{50}$ concentration. Thus,
\% germination differed significantly @ 0.05 level of significance in the two different concentrations. On taking seedling length (Shoot length + Root length) into consideration, it was higher $(53.02 \mathrm{~cm})$ in $\mathrm{LD}_{95}$ concentration when compared with control $(46.99 \mathrm{~cm})$ and $L_{50}$ concentration (47.37 cm) (Fig.2.). Vigour index was maximum (5195.96) at LD 95 concentration whereas it was lower in untreated control (4511.04). Diatomaceous Earth is rich in minerals like silica, alumina and iron oxide and considered beneficial for plant growth that enhances seedling relative growth rate, vigour and seedling cotyledon growth (Sun et al., 2021). By taking this into consideration, the current results showed higher seedling growth rates in $L D_{95}$ concentration, indicating that amorphous silica has been absorbed by the maize seeds and thus actively involved in the germination process. Similarly, higher dry matter production was noticed in $L D_{95}$ treatment $(2.6 \mathrm{~g})$ than $L D_{50}$ concentration and (2.5 and $2.1 \mathrm{~g}$, respectively).

Further, DE is mainly composed of amorphous silica and it can be used as a supplement to silica in the fertilization of crops for biotic and abiotic stresses. Pati et al. (2016) proved that the application of DE enhanced

Table 3. Effect of DE on germination and seedling parameters in maize $\left(7^{\text {th }}\right.$ day)

\begin{tabular}{llllllll}
\hline Treatment & $\begin{array}{l}\text { Germination } \\
(\%)\end{array}$ & $\begin{array}{l}\text { Shoot } \\
\text { length }(\mathbf{c m})\end{array}$ & $\begin{array}{l}\text { Root length } \\
(\mathbf{c m})\end{array}$ & $\begin{array}{l}\text { Seedling } \\
\text { length }(\mathbf{c m})\end{array}$ & $\begin{array}{l}\text { Vigor } \\
\text { index }\end{array}$ & $\begin{array}{l}\text { Initial fresh } \\
\text { weight (g) }\end{array}$ & $\begin{array}{l}\text { After dry } \\
\text { weight (g) }\end{array}$ \\
\hline Control & $96^{\mathrm{ab}} \pm 0.94$ & $21.30^{\mathrm{c}} \pm 0.06$ & $25.69^{\mathrm{b}} \pm 0.22$ & $46.99^{\mathrm{b}} \pm 0.43$ & 4511.04 & $14.2^{\mathrm{c}} \pm 0.03$ & $2.1^{\mathrm{c}} \pm 0.01$ \\
DE LD & $94^{\mathrm{b}} \pm 1.11$ & $22.29^{\mathrm{b}} \pm 0.24$ & $25.08^{\mathrm{c}} \pm 0.13$ & $47.37^{\mathrm{b}} \pm 0.20$ & 4547.52 & $16.2^{\mathrm{b}} \pm 0.17$ & $2.5^{\mathrm{b}} \pm 0.02$ \\
DE LD & $98^{\mathrm{a}} \pm 0.18$ & $26.26^{\mathrm{a}} \pm 0.21$ & $26.75^{\mathrm{a}} \pm 0.09$ & $53.02^{\mathrm{a}} \pm 0.63$ & 5195.96 & $18^{\mathrm{a}} \pm 0.20$ & $2.6^{\mathrm{a}} \pm 0.03$ \\
SEd & 1.8389 & 0.2650 & 0.2182 & 0.6444 & & 0.2159 & 0.0294 \\
CD $(0.05)$ & 4.0066 & 0.5775 & 0.4755 & 1.4041 & & 0.4705 & 0.0640 \\
\hline
\end{tabular}

Means \pm SE within a column followed by the same letter is not significantly different from each other at $5 \%$ level of significance (LSD) 
the development and uptake of nutrients in field crops. Similarly, Mills-Ibibofori et al. (2019). revealed that DE supplementation in ornamentals resulted in positive effects against stress tolerance in flower and leaf features development. The earlier findings are in accordance with the present results. Therefore, treating DE in storage acts as an effective protectant against storage pests and as a potential supplement to silicon fertilizer which may be considered as an added advantage.

\section{Conclusion}

Contact toxicity studies of DE on $S$. oryzae revealed $L_{50}$ at the concentration of $1.27 \mathrm{mg} / 100 \mathrm{~g}$ and $L D_{95}$ at the concentration of $86.11 \mathrm{mg} / 100 \mathrm{~g}$. Among the treatments, $L D_{95}$ was more effective in the case of both entomotoxic and germination studies. At $L D_{95}$ concentration, almost $95 \%$ of the weevils were killed, thus making it an effective dose. Maximum mortality could be obtained within 5 days of exposure and insect mortality increased with an increase in dosage and period of exposure. In addition to toxicity, DE positively affected the agro-morphological characters (shoot length, root length, germination percentage, dry matter production and seedling vigour) of maize seeds. Thus, DE can be effectively deployed in the field of storage as a potent seed protectant against major storage pests like S. oryzae.

\section{Conflict of interest}

The authors declare that they have no conflict of interest.

\section{REFERENCES}

1. Athanassiou, C. G., Kavallieratos, N. G. \& Andris, N. S (2004). Insecticidal effect of three diatomaceous earth formulations against adults of Sitophilus oryzae (Coleoptera: Curculionidae) and Tribolium confusum (Coleoptera: Tenebrionidae) on oat, rye, and triticale. Journal of Economic Entomology, 97(6), 2160-2167. https://doi.org/10.1093/jee/97.6.2160.

2. Athanassiou, C. G., Kavallieratos, N. G., Vayias, B. J., Tsakiri, J. B., Mikeli, N. H., Meletsis, C. M. \& Tomanovic, Z. (2008). Persistence and efficacy of Metarhizium anisopliae (Metschnikoff) Sorokin (Deuteromycotina: Hyphomycetes) and diatomaceous earth against Sitophilus oryzae (L.) (Coleoptera: Curculionidae) and Rhyzopertha dominica (F.) (Coleoptera: Bostrychidae) on wheat and maize. Crop Protection, 27(10), 1303-1311. http:// dx.doi.org/10.1016/j.cropro.2008.03.004

3. Athanassiou, C. G., Vayias, B. J., Dimizas, C. B., Kavallieratos, N. G., Papagregoriou, A. S. \& Buchelos, C. T. (2005). Insecticidal efficacy of diatomaceous earth against Sitophilus oryzae (L.) (Coleoptera: Curculionidae) and Tribolium confusum du Val (Coleoptera: Tenebrionidae) on stored wheat: influence of dose rate, temperature and exposure interval. Journal of Stored Products Re- search, 41(1), 47-55. https://doi.org/10.1016/j.jspr.200 3.12.001

4. Badii, B. K., Adarkwah, C., Obeng-Ofori, D. \& Ulrichs, C. (2014). Efficacy of diatomaceous earth formulations against Callosobruchus maculatus (F.)(Coleoptera: Bruchidae) in Kersting's groundnut (Macrotyloma geocarpum Harms): influence of dosage rate and relative humidity. Journal of pest science, 87(2), 285-294. https:// doi.org/10.1007/s10340-013-0548-0

5. Desmarchelier, J. M. \& Dines, J. C. (1987). Dryacide treatment of stored wheat: its efficacy against insects, and after processing. Australian Journal of Experimental Agriculture, 27(2), 309-312. https://doi.org/10.1071/ EA9870309

6. Ebeling, W. (1971). Sorptive dusts for pest control. Annual Review of Entomology, 16(1),123-158. https://doi.or g/10.1146/annurev.en.16.010171.001011

7. El-Aziz, A. \& El-Ghany, A. (2018). Impact of Diatomaceous Earth Modifications for Controlling the Granary Weevil, Sitophilus granarius (Linnaeus)(Coleoptera: Curculionidae). Journal of Agricultural Science and Technology, 20(3), 519-531

8. Erturk, S., Atay, T., Toprak, U. \& Alkan, M. (2020). The efficacy of different surface applications of wettable powder formulation of Detech ${ }^{\circledR}$ diatomaceous earth against the rice weevil, Sitophilus oryzae (L.) (Coleoptera: Curculionidae). Journal of Stored Products Research, 89, 101725. https://doi.org/10.1016/j.jspr.2020.101725

9. Fields, P.G. \& Muir, W.E. (1996). Physical Control. In Subramanyam \& D.W. Hagstrum (Eds.), Integrated Management of Insect in Stored Products. (pp. 195-221). New York: Marcel-Dekker Inc.

10. Gad, H. A., Al-Anany, M. S. \& Abdelgaleil, S. A. (2020). Enhancement the efficacy of spinosad for the control Sitophilus oryzae by combined application with diatomaceous earth and Trichoderma harzianum. Journal of Stored Products Research, 88, 101663. https:// doi.org/10.1016/j.jspr.2020.101663

11. Govindaraju, K., Tamilselvan, S., Kannan, M., Kathickeyan, D., Doron, S. \& Sumit, C (2020). Nano-micronutrients [Y-Fe 203 (iron) and $\mathrm{ZnO}$ (zinc)]: green preparation, characterization, agro-morphological characteristics and crop productivity studies in two crops (rice and maize). New Journal of Chemistry, 44(26), 11373-11383. https://doi.org/10.1039/D0NJ02634D

12. International Seed Testing Association. (1999). International rules for seed testing. Rules 1999 (No. Suppl).

13. Islam, M. S., Hasan, M. M., Lei, C., Mucha-Pelzer, T., Mewis, I. \& Ulrichs, C. (2010). Direct and admixture toxicity of diatomaceous earth and monoterpenoids against the storage pests Callosobruchus maculatus (F.) and Sitophilus oryzae (L.). Journal of Pest Science, 83(2), 105-112. https://doi.org/10.1007/s10340-009-0276-7

14. Korunic, Z. (1997). Rapid assessment of the insecticidal value of diatomaceous earths without conducting bioassays. Journal of Stored Products Research, 33(3), 219229. https://doi.org/10.1016/S0022-474X(97)00004-0

15. Korunic, Z. \& Fields, P. (1998). U.S. Patent No. $5,773,017$. Washington, DC: U.S. Patent and Trademark Office. 
Aisvarya, S. et al. / J. Appl. \& Nat. Sci. 13(4), 1180 - 1186 (2021)

16. Korunic, Z. \& Fields, P. G. (2006, October). Susceptibility of three species of Sitophilus to diatomaceous earth. In Proceedings of the 9th International Conference on Stored-Product Protection. ABRAPOS, Rodovia (pp. 681 686).

17. Korunic, Z., Fields, P. G., Timlick, B., Ormesher, P. \& Van Natto, C. (1997). The enhanced diatomaceous earth, a safe, effective and long-lasting grain protectant. Food and Agriculture Organization. In Presented at Food and Agriculture Organization, VIII Round Table on Prevention of Post-Harvest Food Losses, Columbia, Cartagena.

18. Korunic, Z., Rozman, V., Liska, A. \& Lucic, P. (2017). Laboratory tests on insecticidal effectiveness of disodium octaborate tetrahydrate, diatomaceous earth and amorphous silica gel against Sitophilus oryzae (L.) and their effect on wheat bulk density. Poljopr. Agric, 23, 3-10. https://doi.org/10.18047/poljo.23.1.1

19. Maceljski, M. \& Korunic, Z. (1972). The Effectiveness against Stored-Product Insects of Inert Dusts, Insect Pathogens, Temperature and Humidity. Zagreb, Croatia. Project No. E30-MQ-1. Grant USDA/YU No. FG -YU - 130. Final Report of Institute for Plant Protection.

20. Mewis, I. \& Ulrichs, C. (2001). Action of amorphous diatomaceous earth against different stages of the stored product pests Tribolium confusum, Tenebrio molitor, Sitophilus granarius and Plodia interpunctella. Journal of Stored Products Research, 37(2), 153-164. https://doi.org/10.10 16/S0022-474X(00)00016-3

21. Mills-lbibofori, T., Dunn, B., Maness, N. \& Payton, M. (2019). Use of diatomaceous earth as a silica supplement on potted ornamentals. Horticulturae, 5(1), 21. https:// doi.org/10.3390/horticulturae5010021

22. Omobowale, M. O. \& Akomolafe, O. P. (2021). Efficacy of Diatomaceous Earth and Vitellaria paradoxa Seed Oil in
Storage of Cowpea under Ventilated and Non-ventilated Conditions. Journal of Experimental Agriculture International, 70-81. https://doi.org/10.9734/jeai/2021/v43i330658

23. Pati, S., Pal, B., Badole, S., Hazra, G. C. \& Mandal, B. (2016). Effect of silicon fertilization on growth, yield, and nutrient uptake of rice. Communications in Soil Science and Plant Analysis, 47(3), 284-290. https://doi.org/10.108 0/00103624.2015.1122797

24. Prasantha, B. R., Reichmuth, C., Adler, C. \& Felgentreu, D. (2015). Lipid adsorption of diatomaceous earths and increased water permeability in the epicuticle layer of the cowpea weevil Callosobruchus maculatus (F.) and the bean weevil Acanthoscelides obtectus (Say) (Chrysomelidae). Journal of Stored Products Research, 64, 36-41. https://doi.org/10.1016/j.jspr.2015.08.0 03

25. Shah, M. A. \& Khan, A. A. (2014). Use of diatomaceous earth for the management of stored-product pests. International journal of pest management, 60(2), 100-113. http://dx.doi.org/10.1080/09670874.2014.918674

26. Subramanyam, B. \& Roesli, R. (2000). Inert dusts. In Alternatives to pesticides in stored-product IPM (pp. 321-380). Springer, Boston, MA. http://dx.doi.org/1 0.1007/978-1-4615-4353-4_12

27. Sun, Y., Xu, J., Miao, X., Lin, X., Liu, W. \& Ren, H. (2021). Effects of exogenous silicon on maize seed germination and seedling growth. Scientific Reports, 11(1), 1-13. https://doi.org/10.1038/s41598-020-79723-y

28. Tadese, A. (1997). Arthropods associated with stored maize and farmers' management practices in the Bako area, Western Ethiopia. Pest Management Journal of Ethiopia (Ethiopia).

29. Ziaee, M., Ebadollahi, A. \& Wakil, W. (2019). Integrating inert dusts with other technologies in stored products protection. Toxin reviews, 1-16. 